\title{
Value management models for financial resilience estimations. A case of selected industrial companies in the Republic of Moldova
}

\author{
Iurie BEȘLIU*, Oleg PETELCA**, Veronica GARBUZ***
}

\begin{abstract}
The object of the research is the financial resilience mechanism of the company focused on value management indicators. The aspect of financial resilience has been combined with enterprise value management in a crisis situation. The value management system was researched using the data from the financial reports of 32 joint-stock companies, the most representative for the industrial sector of the Republic of Moldova. Three models of financial resilience of the enterprise based on value management were applied: the operative value management model, the strategic value management model, and the econometric model. The results of the research showed the existence of a positive influence of the balance sheet value of equity and net residual profit on the value of the enterprise. The financial resilience based on the enterprise value determined according to the market capitalization can be achieved by the balance sheet value of equity and residual profit.
\end{abstract}

Keywords: resilience, financial resilience, resilience model, value management, crisis situation

\section{Introduction}

The economic instability of the Republic of Moldova against the background of global financial crises requires a new approach to financial and managerial processes, the adoption of new models and strategies of financial resilience, which will find landmarks to maintain and increase the value of domestic enterprises in crisis conditions. The turning processes that took place during the global financial

\footnotetext{
*Iurie BEŞLIU is PhD at Alecu Russo State University, Republic of Moldova, e-mail: iurie.besliu@gmail.com.

** Oleg PETELCA is PhD student at Alexandru Ioan Cuza University of Iaşi, Romania, email: oleg.petelca@gmail.com.

${ }^{* * *}$ Veronica GARBUZ is Associate professor at Alecu Russo State University, Republic of Moldova, e-mail: garbuz_veronica@yahoo.com.
} 
crisis amplify the actuality of the development of the financial resilience methodology. The unpredictable dynamics of the market, the fierce competition, the multitude of norms, and legislative acts, create countless obstacles for Moldovan companies in terms of development. Under these conditions, conceptual innovations in the financial management of the company are becoming essentially important for domestic companies.

The practice of developed countries shows that value has several unique properties, which make it the best criterion for making management decisions in a crisis situation and, in a broader sense - the best criterion for assessing the success of company management, in general. When used correctly, the value criterion makes it possible to make effective decisions that can improve the long-term economic situation of companies and contribute to their financial resilience.

Aghimien et al. (2018) argued that the use of value management became popular in most developed countries in the 1970s. The potential advantages of market value have long been recognized, but analytical results were very limited (Modigliani and Miller, 1958). This concept became more popular in the 1990s and 2000s among companies operating in market economy countries.

The necessary conditions for the development of the concept of value management were highlighted in the works of scientists Modigliani, and Miller (1958). The research of these authors was based on the examination of the value in terms of discounted cash flow and capital structure. These ideas have become widespread, both in the field of theoretical value science and in the practical work of finance specialists.

As main models, which are the basis for the development of value management methods, we can highlight the following: Damodaran (2012), Copeland-Koller-Murrin (2000), and Walsh (1996).

Damodaran, Copeland-Koller-Murrin, and Walsh considers that the management of the company's value can be carried out based on discounted cash flows. Copeland et al. (2000) consider that the basis for value management is the decision on the rationality of the company's restructuring (in particular after detecting that the value of the company's net assets is greater than the value of share capital, determined by using the discounted cash flow method) and analysis of the possible consequences of restructuring and, for this reason, they propose the use of the classical pentagram of restructuring possibilities. Walsh (1996) investigated another important aspect of managing the company's value, namely, the balance between profit, assets, and growth.

In the literature, the issue of financial resilience of the company through the perspective of the company's value management is practically not addressed. The possibilities of using a company's value in enterprise management in the process of merger and takeover of enterprises are researched (Damodaran, 2012; Evans and Bishop, 2001; Reilly and Schweihs, 2014) but some sources address the issue given in terms of management and evaluation of insolvent enterprises at various stages of 
the insolvency process (Chernozub, 2010). Although previous studies have discussed the benefits, activities, and effectiveness of value management in several countries, no effort has been made to determine the effects of implementing value management on the financial resilience of companies in developing countries. Value management methods have not received comparable coverage in most developing countries (Kim et al., 2016). Based on the value management model in crisis conditions, the authors aim to formulate the financial resilience mechanism focused on a system of indicators, which will provide the company's management with relevant information about the results and dynamics of the company's development.

To achieve this goal, the paper continues by briefly introducing the main theoretical explanations that could illustrate the factors that influence the financial resilience of the company. Section 2 provides information on data collection and the methodological approach used to conduct the research, and then, Section 3 presents the results and discusses the findings. Finally, section 4 is devoted to the conclusions.

\section{Literature review}

According to corporate finance theory, the economic value of any investments is determined by the sum of the present value of future cash flows. Based on the given theoretical statement, to most researchers (Brealey et al., 2020; Damodaran, 2012), the notion of enterprise value is the utility (in the form of future flows) generated by all assets of the enterprise.

In their article, "The Cost of Capital, Corporation Finance and the Theory of Investment" (1958), American Nobel laureates Modigliani and Miller (1958) showed that the enterprise value is determined solely by its future income and does not depend on the ratio of share capital to borrowed capital.

A considerable contribution to the development of the concept of enterprise value belongs to Gordon and Shapiro (1956), who developed the model for estimating the value of share capital which later created the foundation for the development of current methods of enterprise valuation, adapted to the specific conditions of the contemporary economy.

\subsection{Conceptual aspects regarding the value of the enterprise}

A perspective direction in the field of enterprise value theory was developed by Ohlson in the $90 \mathrm{~s}$. Its essence lies in the fact that the enterprise value is determined by the current assets and the surplus profits obtained by the enterprise.

A similar view is held by Rutgayzer (2014), who defines the value of the enterprise as "equivalent of the current value of future benefits from the enterprise activity".

At the same time, Bodie and Merton (2004) state that the enterprise value does not correspond to the present value of future profits, but may be higher or lower than 
the existing market value. The coincidence is dictated by the fact that the volume of net investments can be both positive and negative. The authors demonstrate that the value of the enterprise must be equal to the difference between the present values of future profit and reinvested profit.

Ioniță (2007) establishes that "the evaluation of the organization does not only imply the determination of the value of some properties or assets from its patrimony, but also the determination of its capacity to generate cash flows that will benefit the owner of the organization, as it is a good that, in turn, generates goods".

From the definitions presented above, we can note that the concept of enterprise value is defined differently by various researchers, some considering that the enterprise value is determined by the value of the assets of the enterprise, others by the possibilities of efficient use of given assets, to generate stable and increasing cash flows. Therefore, we note that a common element of all definitions is the financial aspect of the concept of enterprise value, which additionally demonstrates that the enterprise value is directly influenced by the financial activity of the company. Respectively, in the process of enterprise managing and assessing its resilience, financial factors that constitute an internal potential of the enterprise and that have a considerable impact on value management must be taken into account. However, we find that the researched definitions do not disclose the aspect of value as an enterprise management tool and indicator of the financial resilience of the company, which would create new opportunities to use value in the decision-making and managerial processes of the company.

In our opinion, an important role in the efficient management of the enterprise from the value positions can be identified in the definition of the concept of enterprise value. In the view of the authors of this research, enterprise value is an analytical indicator for estimating the efficiency of the company's activity, which characterizes the prospects of the company's resilience, the efficiency of managing the company's assets and liabilities to generate stable and increasing benefits for owners, managers, employees, creditors, state and society in general.

The definition proposed by us extends and concretizes the essence of the realization of the value and favours the construction of an efficient system of management of the processes of formation of the value, in particular, and a system of enterprise resilience, in general. In the author's view, if the object of evaluation is an operating enterprise, then, its value must be determined not only to establish the value of the alienation but also to manage the processes of financial resilience for a stable operation.

The researched definitions allowed the authors to establish and choose the variables used in estimating the financial resilience models of the enterprise based on the enterprise value, namely: financial profitability, invested capital (equity), operating residual profit, and net residual profit. 


\subsection{Value-based management (VBM)}

VBM can be determined as an aspect of enterprise management that is formally and systematically aimed at achieving the goal of maximizing the value creation process and maximizing long-term shareholder value. Copeland et al. (2000, p. 93) identifies VBM as an aspect of management in which the general tasks of the enterprise, analytical techniques, and management processes are oriented towards maximizing the value of the enterprise by focusing the decision-making process on value creation key factors. At the same time, as Jensen (2001) points out, establishing long-term maximization of value as the main goal does not provide, in itself, management with a strategy to achieve this goal.

At the heart of the concept of VBM is the problem of measuring value and the process of creating it. The evaluation module as a part of VBM involves choosing the model and procedures for determining the enterprise value for its owners, monitoring the change in value (for example through its systematic diagnosis), determining the mechanisms for creating new value.

In the context of the research conducted, we propose the following definition of the notion of "enterprise value management": - a management method which involves a cyclical and continuous process of strategic and operational decisions at all levels of the company (from board to operational level managers) to maximize the current and future value of the enterprise, based on a system of interdependent indicators with an impact on value. In a simpler sense, by value management, we mean all decisions and measures aimed at changing the current value of the company.

Guided by the principles of value management, we believe that companies can make much more efficient and reasonable decisions, regardless of their operating conditions and operational purposes. Value, as the best economic indicator, allows achieving much clearer and more precise goals, because the demand of any market participant is subject to price evaluation.

\subsection{Corporate crises and resilience: approaches in terms of enterprise value}

In the modern economic literature, the concept of the crisis situation of the enterprise is described as a variety of phenomena in the life of the production environment, from a disturbance in the functioning of the enterprise determined by various conflicts, to the destruction of the enterprise as an economic entity. Therefore, in a broad sense, a crisis means a process that threatens the existence of an enterprise.

The crisis situation of the enterprise is defined in the specialized literature as follows: 
- a combination of external and internal factors that adversely affect the production and financial activities of the enterprise and lead to a reduction or cessation of its main activity (Ivashkovskaya et al., 2004, p. 24);

- disruption of economic growth, either to previous growth or to estimated growth (Tsvetkov, 2012);

- lack of funds to maintain current economic and financial needs for working capital (Ayvazyan and Kirichenko, 1999, p. 95);

- significant breach of the established system of social and industrial relations, associated with the loss of previously available resources as a result of changes in significant factors of system formation and breach of previous stable characteristics (Korotkov, 2012, p. 28).

However, such an interpretation, in our view, is not complete. In our research, we will use the following definition of the crisis situation concept: an unplanned and unwanted process, limited in time, which can block or even make the operation of the company impossible and which is, essentially, a turning point in the sequence of events and actions.

A concept close to the concept of crisis is the concept of resilience. Currently, in the modern scientific community, there is no common understanding of the concept of resilience, the popularity of the concept of resilience has increased in various disciplines, including economics, psychology, agriculture, environment, physics, political science, etc. But still, economic resilience can be considered an ambiguous notion that presents different interpretations (Volkov et al., 2021).

Two main approaches to resilience are used in the economic literature. The first refers to resilience as the ability of the system to return to its pre-shock equilibrium state, either to the growth path it would have been in if the shock had been absent (Angulo et al., 2018; Fingleton et al., 2012) or to its ability to absorb the shocks that have the potential to throw it out of its growth path (Wolman et al., 2017). The second approach sees resilience as the ability to absorb, adapt to, or transform into a better development path while maintaining its key functions and performance (Martin and Sunley, 2015).

Rose and Liao (2005) described economic resilience as "the inherent capacity and adaptive response that allows firms and regions to avoid maximum potential losses". Static economic resilience is being referred to by Rose (2007) as the ability of an entity or system to continue its functionality, such as production when faced with severe shock faces, while economic dynamics is defined as the speed at which a system recovers from a severe shock to achieve a state of equilibrium. A more specific definition of economic resilience is presented by Martin (2012) as "the ability to reconfigure, i.e. to adapt its structure (firms, industries, technologies, institutions) to maintain an acceptable path of growth in production, employment labour, and wealth overtime".

Financial resilience in the context of enterprise value management presents the creation of a system of principles and methods, the elaboration and 
implementation of a complex of managerial decisions aimed at preventing and overcoming the reduction of enterprise value, as well as minimizing negative consequences on the enterprise.

The main purpose of managing the enterprise value in a crisis situation is the financial resilience of the enterprise which aims to minimize the reduction of its value, caused by financial crises.

Studying the peculiarities of corporate crises (Ayvazyan and Kirichenko, 1999; Modigliani and Miller, 1958; Tsvetkov, 2012), the authors summarize the following characteristic features of the crisis: unpredictability, threat, and lack of time for reaction. In particular, Ansoff (2009), one of the founders of strategic management, mentions the following as defining features of crisis situations within the enterprise: the threat of existence and the acute shortage of time for the adoption of anti-crisis measures.

\section{Figure 1. The strategies for financial resilience of crisis situations through the perspective of the enterprise value}

\begin{tabular}{|c|c|c|c|}
\hline $\begin{array}{l}\text { The basic } \\
\text { criteria of } \\
\text { the crisis }\end{array}$ & $\begin{array}{l}\text { Characteristic } \\
\text { of the crisis of } \\
\text { the enterprise }\end{array}$ & $\begin{array}{l}\text { The vectors of } \\
\text { the enterprise } \\
\text { crisis research }\end{array}$ & $\begin{array}{l}\text { The vectors of } \\
\text { action in } \\
\text { financial } \\
\text { resilience }\end{array}$ \\
\hline Threat & $\begin{array}{l}\text { Making threats } \\
\text { in the context of } \\
\text { priority } \\
\text { development } \\
\text { goals }\end{array}$ & $\begin{array}{l}\text { Threatening the } \\
\text { priority goals } \\
\text { of the } \\
\text { enterprise }\end{array}$ & $\begin{array}{l}\text { Controlling the } \\
\text { evolution of the } \\
\text { value of the } \\
\text { enterprise, } \\
\text { creating the } \\
\text { strategic value } \\
\text { management } \\
\text { model }\end{array}$ \\
\hline $\begin{array}{l}\text { Unpredict- } \\
\text { ability }\end{array}$ & $\begin{array}{l}\text { The collapse of } \\
\text { management } \\
\text { mechanisms }\end{array}$ & $\begin{array}{l}\text { Specificity of } \\
\text { anti-crisis } \\
\text { management }\end{array}$ & $\begin{array}{c}\text { Creating the } \\
\text { crisis diagnosis } \\
\text { system }\end{array}$ \\
\hline $\begin{array}{l}\text { Time deficit } \\
\text { for reaction }\end{array}$ & $\begin{array}{c}\text { The need for } \\
\text { immediate anti- } \\
\text { crisis } \\
\text { intervention }\end{array}$ & $\begin{array}{c}\text { The shortage of } \\
\text { time as a } \\
\text { condition of the } \\
\text { activity of the } \\
\text { enterprise }\end{array}$ & $\begin{array}{l}\text { Creating the } \\
\text { operational value } \\
\text { management } \\
\text { model }\end{array}$ \\
\hline
\end{tabular}

Source: Authors' representation

According to the authors, the process of financial resilience of the company must be viewed with the general characteristics of the crisis situations described above. Taking into account the proposed logic, we will further address the content of the financial resilience process of the company's crisis situations and their correlation with the company's value management system, which will later allow us 
to argue the financial resilience mechanism involving the company's value. The results obtained are presented in a synthetic form in Figure 1.

For each of the basic criteria of crisis situations presented in Figure 1, the authors establish the characteristics that correspond to each criterion, the crisis neutralization mechanism, which then allow arguing on the vectors to ensure the financial resilience of the company in terms of value. Therefore, the threat criterion is associated with the existence of a crisis of the enterprise strategy, which is less visible and not so immediate and occurs when the development potential of the enterprise (innovation potential) is substantially damaged, exhausted, and (or) a new one cannot be created. Although the current position of the company (success situation) seems quite satisfactory, the crisis offensive should be diagnosed to detect failures in the development of the company.

The problem of detecting deviations from the priority development goals of the enterprise is solved by controlling the evolution of the enterprise value, which can be achieved by creating a model of strategic management of the enterprise value. The elaboration of such a model will allow the neutralization of the crisis threat criterion.

The strong point of this approach is to highlight the early stages of the crisis (potential crisis and latent crisis), thus providing the opportunity to examine the process of triggering the crisis in detail, which increases the likelihood of resolving the crisis.

The criterion of the unpredictability of the crisis leads to the collapse of management mechanisms and can seriously affect the management system of the enterprise by the sudden intensification of the destructive processes. It is important not to lose control of events, which develop with great speed and intensity. To neutralize the unpredictability criterion and ensure the financial resilience of the enterprise, we consider it important to implement a crisis diagnosis system. The problem of crisis diagnosis can be solved by developing an econometric model, which would monitor the evolution of the enterprise value and, in case of a negative trend, will signal the management of the enterprise to expect a crisis.

In order to manage the lack of time for the reaction, an immediate intervention with anti-crisis solutions is needed, which will be solved by developing a model of operative management of the enterprise value.

In this article, we will focus on developing models of operative management and strategic management of enterprise value and econometric model, which will allow us to annihilate the criteria of threat, unpredictability, and lack of time for reaction in the process of triggering corporate crises. These models will increase the inherent capacity of enterprises to continue their functionality in crisis situations and will help to avoid the negative consequences of crises, i.e. will increase the financial resilience of enterprises. 


\section{Data and methodology}

To achieve the objectives proposed by the authors, empirical research was conducted based on data on the financial activity of industrial enterprises in the Republic of Moldova for 2012-2017. A number of 32 joint-stock companies were selected, representing the domestic industrial sector and the economy of the Republic of Moldova, with total sales of 274.4 million euros in 2012 and 347.9 million euros in 2017 , which is $13.5 \%$ of the volume of industrial production of the domestic industrial sector for 2017. One of the arguments for focusing the research on large industrial enterprises is because the implementation of the concept of value management is currently at a certain conceptual level of enterprise development, and the selected enterprises correspond to the stage of maturity-decline of the life cycle. The second argument is related to the organizational and legal form of the selected companies which, being joint-stock companies, have a corporate governance structure, which allows us to study the decision-making processes of a complex administration, based on the different interests of the actors involved in the decisionmaking process. The third argument relates to the possibility of investigating the correlation between the market capitalization and fundamental value of the enterprise because the shares of the selected industrial enterprises are listed on the Moldavian Stock Exchange (MSE).

The authors applied three models of financial resilience of the enterprise based on value management: the operative value management model, the strategic value management model, and the econometric model.

\subsection{The model of operative management of the enterprise value}

The operative management model contains a system of indicators, related to the enterprise value, which can perform specific functions - with their help, managers can assess the impact of some or other operational decisions on the value of the entire company.

According to the authors' opinion, the financial factors of the value can be divided into four groups of indicators: those which reflect the strategic efficiency of the enterprise, the efficiency of the operational, investment and financial activity, and the model that unites these indicators is the sustainable growth model (SGM).

SGM implies the maximum level of growth of the enterprise that can be achieved and maintained by the enterprise without attracting external sources of financing (Patel et al., 2020). In other words, the sustainable growth rate (SGR) is the rate of increase in sales that the enterprise can achieve if its financial and operational policy remains unchanged (Ivashkovskaya, 2021). The following relation can estimate SGR:

$$
S G R=R O E \times R,
$$


where ROE - financial profitability, R - accumulation rate of profit (not paid through dividends), which is estimated based on the relation:

$$
R=\left(1-\frac{\text { Dividends }}{\text { Net profit }}\right)
$$

The strong point of this indicator lies in its integrity, because the factors included allow following the company's activity as a whole. With the help of this model, we can evaluate the markets of the company's products, the products themselves, as well as the financial activity of the company.

Figure 2. The factorial model for analysing the sustainable growth rate

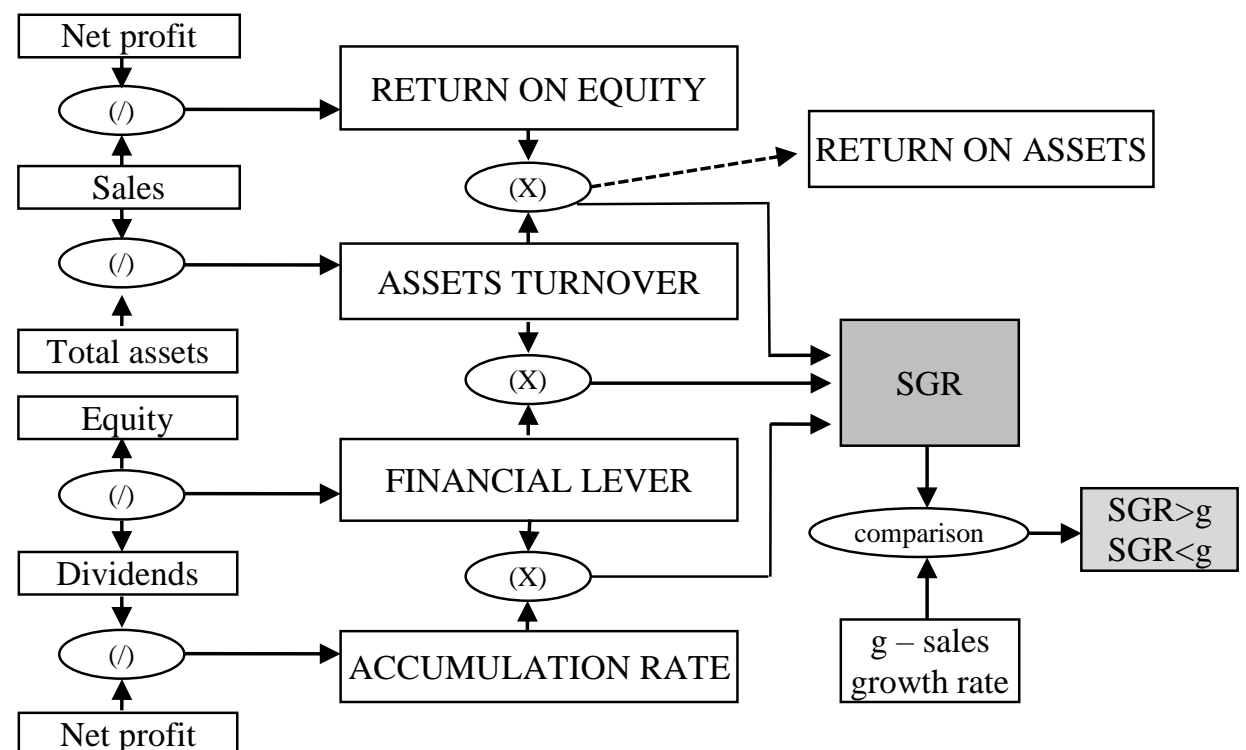

Source: Authors' representation

We can check if the financial activity can support the production activity and the marketing plans. If our growth potential is insufficient, we can decide to change the return on sales, the asset turnover ratio, the financial lever, the reinvestment ratio.

To further investigate the causes that had a positive and negative impact, respectively, both on individual enterprises and in general, we used the SGR factorial analysis process and developed the SGR factor analysis model, presented in Figure 2.

To assess the use of the growth potential of industrial enterprises, we used the comparison of SGR indicator with the sales growth rate. The combination of methodological aspects and practical tools for managing the enterprise value was 
designed by using the models of strategic analysis known, first of all: the 5 market forces model, the value creation chain (Porter, 2008), and the positioning matrices (General Electric, BCG, Ansoff (2009), Kearney).

\subsection{The model of strategic management of the enterprise value}

The model of strategic management presupposes the value diagnosis based on the residual profit model (MPR), which assumes that the fundamental value of an enterprise's equity depends on the size of the capital invested at the time of valuation, de facto return on capital; the requested return on capital; the period of competitive advantages, i.e. the ability of the enterprise to generate a return on capital higher than the required one.

In general, the residual profit size can be expressed by the formula:

$$
P R_{j}=\pi_{j}-\kappa \cdot I_{j-1},
$$

where $P R_{\mathrm{j}}$ - the residual profit of the current period; $\pi_{\mathrm{j}}$ - the accounting profit for the current period, $\mathrm{k}$ - the requested return on capital; $\mathrm{I}_{\mathrm{j}-1-1}$ the balance sheet value of investments at the beginning of the period (the period preceding the current one).

Depending on what is understood by investments in the organization, we can highlight two variants of the residual profit indicator: the operational residual profit and the net residual profit.

The operational residual profit (PRO) is the net operating profit of the enterprise minus the expenses with the entire capital of the enterprise.

The essence of the indicator of the operational residual profit consists of the net operational effects of the activity of the enterprise, therefore when calculating, the investment value is understood as the net asset value (AN) which, in turn, is determined as the difference between the general size of the assets and the free attracted debts (most of the creditors). The net operating profit indicator is taken appropriately as a profit, that is, the profit indicator until the payment of interest, but after the payment of taxes (PPD).

Therefore, as requested, profitability will be the rate of weight average cost of capital (WACC). Then, the formula for calculating the operational residual profit will have the form:

$$
P R O_{j}=P P D_{j}-W A C C \cdot A N_{j-1}
$$

The net residual profit (PRN) constitutes the net profit of the organization minus the capital expenditures. The PRN indicator characterizes the net effects of the results of the enterprise activity directly from the position of the shareholders. Then, the formula for calculating the net profit will have the form: 


$$
P R N_{j}=P n_{j}-C C P \cdot C P_{j-1}
$$

where, CP - the balance sheet value of the own capital, Pn - net profit, CCP - the equity expenditure rate.

\subsection{The econometric model for estimating enterprise resilience}

A series of researches by the international scientific community (Courteau $e t$ al., 2001; Penman and Sougiannis, 1998; Penman and Yehuda, 2009), based on data from developed financial markets, show that residual profit models can better explain the stock market of listed companies and their dynamics.

For the elaboration of the econometric model, we will start from the model of net residual profit, by which the fundamental value of the company's equity is determined as the sum of the balance sheet value of equity and discounted net residual profit flows.

The market research of the Republic of Moldova conducted by the authors was built on a similar model and aimed to test whether the size of the balance sheet value of equity and net residual profit, as components of the PRN model, can explain the size of the market value of the shares of listed companies. Thus, the verification of the given hypothesis was performed by using the methods of regression analysis against domestic industrial enterprises, whose shares are listed on MSE.

The estimation of the results in the examined models is based on the linear regression technique, which puts various econometric problems in front of the researchers to verify the correctness of the result, related to such properties as heteroscedasticity, autocorrelation, multicollinearity. The problem of estimation is complicated by the natural lack of statistical data on the capital market of the Republic of Moldova. But the rather high degree of variation determined by the result, combined with the importance of all coefficients (which practically excludes the possibility of multicollinearity), can explain the share prices in developing markets.

To perform the regression analysis of the dependence between the fundamental and market value of enterprises' equity, we will use a two-factor model.

We note that the market capitalization is determined as the product of the weighted average market price of the shares with the number of shares issued. At the same time, the fundamental value of equity $\left(\mathrm{V}_{\mathrm{i}}\right)$ is determined as the sum of the equity value of equity $\left(\mathrm{CP}^{\mathrm{VB}}\right)$ and the annuity of net residual profit (PRN) for the current period. Obviously, in that case we use the assumption that the company's PRN will be fixed in subsequent periods. Respectively, the size $V_{i}$ with the reservations made can be calculated according to the formula: 


$$
V_{i}=C P_{i 0}^{V B}+\frac{P R N_{i}}{C C P}
$$

where - $C P_{i 0}^{V B}$ is the balance sheet value of equity at the beginning of the period, at the end of which the valuation takes place; $\mathrm{PRN}_{\mathrm{i}}$ - net residual profit for the period in which the valuation takes place; CCP - required return on capital.

Unlike the unifactorial model, the bifactorial model allows the regression equation to take into account the overall impact of each of the elements that form the fundamental value:

$$
\operatorname{Cap}_{i}=\alpha_{i}+\beta_{1 i} \times C P_{i 0}^{V B}+\beta_{2 i} \times \frac{P R N_{i}}{C C P}+\varepsilon_{i}
$$

where $C a p_{i}$ - market capitalization at the time of valuation; $C P_{i 0}^{V B}$ - the balance sheet value of the equity at the beginning of the period, at the end of which the valuation takes place; $P R N_{i}$ - the net residual profit for the period in which the evaluation takes place; $C C P$ - the requested return on capital; $\alpha_{i}, \beta_{i}-$ parameters of the regression equation, $\varepsilon_{i}$ - random variable.

The sample, based on which the research is carried out, includes the data of the issuing companies, whose shares are listed and traded on MSE. However, to maintain the demand for homogeneity of data in the sample, the actions of financial intermediaries were excluded. Thus, the final sample size was limited to 17 domestic industrial enterprises or 102 enterprise-year observations, which were followed by a six-year period. The data needed for the research were taken from the financial reports of the companies for the years 2012-2017. The average market value of simple shares, presented on the MSE website (www.moldse.md), weighted by the volume of transactions, was considered as data on the market value of the shares.

\section{Results and discussions}

In recent years, the main problem of contemporary Financial Management science has been to develop and propose solutions for the possibility of obtaining long-term benefits from economic crises. The value management models of the enterprise presented in the previous chapter constitute the methodological basis of the financial resilience of enterprises. These models total a wide range of signs of financial instability in the broadest sense and are useful tools in stabilizing the financial situation of companies. In this respect, monitoring the value of enterprises can be considered a methodology in the financial resilience of the enterprise, in particular to justify the methodology of scientific research in this field. 


\subsection{Results of applying the operative management model of the enterprise value}

The analysis of the preliminary indicators of the sample of researched enterprises tells us about the existence of positive dynamics over the period studied for the indicators of sales, total assets, net assets, and share capital. Net profit is also positive, except for the years 2013-2015.

General information on the indicators of the financial activity of joint-stock companies for the years 2012-2017 is shown in Table 1.

Table 1. General characteristics of the sample of the researched enterprises, thousand euro

\begin{tabular}{|c|c|c|c|c|c|c|c|c|c|c|c|c|}
\hline \multirow{2}{*}{$\begin{array}{l}\text { Name of the } \\
\text { indicator }\end{array}$} & \multicolumn{2}{|c|}{2012} & \multicolumn{2}{|c|}{2013} & \multicolumn{2}{|c|}{2014} & \multicolumn{2}{|c|}{2015} & \multicolumn{2}{|c|}{2016} & \multicolumn{2}{|c|}{2017} \\
\hline & 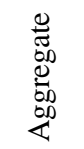 & 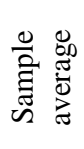 & 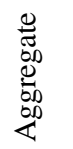 & 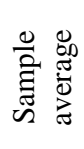 & 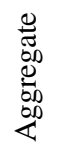 & 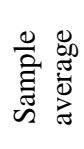 & 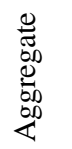 & 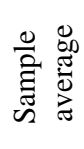 & $\begin{array}{l}0 \\
\stackrel{0}{5} \\
0.0 \\
0 \\
0 \\
00 \\
0\end{array}$ & 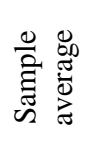 & 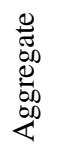 & 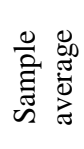 \\
\hline 1. $\mathrm{Sa}$ & 8,7 & & 260,6 & & 287 & & 20 & & 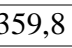 & 11,2 & 9, & 10 , \\
\hline 2. Assets & 299,7 & 9,4 & 327,7 & 10,2 & 347,4 & 10,9 & 362,1 & 11,3 & 409,9 & 12,8 & 453,1 & 14,2 \\
\hline 3. Net : & 184,3 & 5,8 & 187,8 & 5,9 & 192,1 & 6,0 & 199,6 & 6,2 & 227,7 & 7,1 & 243,0 & 7,6 \\
\hline 4. Social & 61,1 & 1,9 & 61,1 & 1,9 & 62,3 & 2,0 & 64,1 & 2,0 & 64,2 & 2,0 & 66,1 & 2,1 \\
\hline 5. Net profit & 7,3 & 0,2 & 4,9 & 0,2 & 6,0 & 0,2 & 5,7 & 0,2 & 14,9 & 0,5 & 15,8 & 0,5 \\
\hline
\end{tabular}

Source: Author's estimations based on the financial reports of industrial enterprises

At a patrimonial evaluation (based on the expenditure method) of the value management process at the researched enterprises, we find that the net assets of industrial enterprises register a positive dynamic, from 184 thousand euro in 2012 to 243 thousand euro in 2017 which, at a first sight, tells us about increasing the welfare of the shareholders of the analyzed companies.

However, to carry out a specific and detailed assessment of the value creation process, we will apply the tools proposed by the authors for the operative management of the enterprise value. 
Figure 3. The evolution of the average SGR and the results of the factor analysis

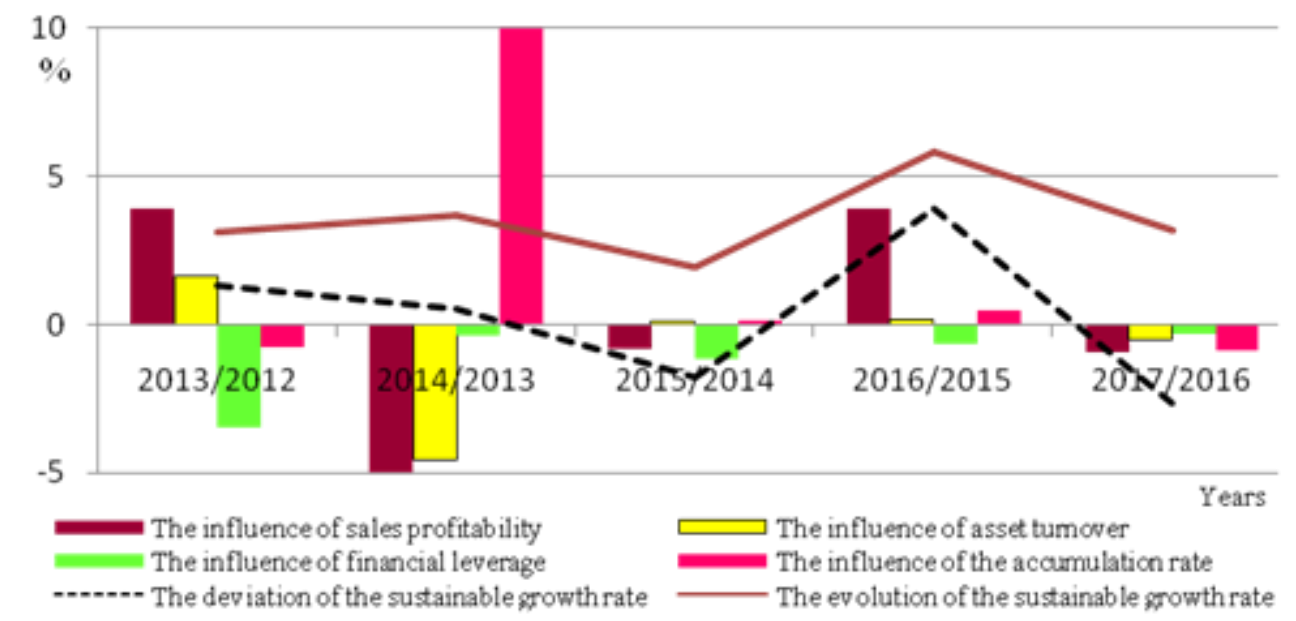

Source: Authors' representation based on the results of his estimations

The determination of the SGR indicator for the years 2012 - 2017 was made based on the data of the financial reports of the domestic industrial enterprises. The sizes of the SGR indicator for the analyzed enterprises are different and are in the range of $-75.08 \%$ to $49.26 \%$. Taking into account the dispersion of the obtained results, we will analyse them by establishing the number of enterprises that registered positive and negative results, respectively, the average values of the indicator for enterprises that registered positive and negative results, as well as the general average on all enterprises from the investigated sample (Table 2).

Table 2. Generalized evaluation of the results of the SGR indicator determination in the domestic industrial enterprises for the years 2012-2017

\begin{tabular}{llrrrrrr}
\hline No. & \multicolumn{1}{c}{ The evaluation result } & $\mathbf{2 0 1 2}$ & $\mathbf{2 0 1 3}$ & $\mathbf{2 0 1 4}$ & $\mathbf{2 0 1 5}$ & $\mathbf{2 0 1 6}$ & $\mathbf{2 0 1 7}$ \\
\hline 1. & Positive result by enterprises, units & 23 & 23 & 24 & 22 & 29 & 25 \\
\hline 2. & Negative result by enterprises, units & 9 & 9 & 8 & 10 & 3 & 7 \\
\hline 3. & $\begin{array}{l}\text { Average value of the positive } \\
\text { result, \% }\end{array}$ & 7.18 & 7.66 & 7.66 & 7.72 & 6.99 & 6.49 \\
\hline $\begin{array}{l}\text { Average value of the negative } \\
\text { result, \% }\end{array}$ & -11.84 & -8.43 & -8.29 & -10.82 & -5.32 & -8.68 \\
\hline 5. & General average, \% & 1.83 & 3.14 & 3.67 & 1.92 & 5.83 & 3.17 \\
\hline
\end{tabular}

Source: Authors' calculations based on the financial reports of industrial enterprises 
The positive result shows that most of the domestic industrial enterprises have a rather high growth potential, respectively, the enterprises with researched shares have a growth capacity without resorting to external financing sources.

In order to graphically evaluate the dynamics of the SGR and the factors with impact on the SGR indicator, the authors resorted to drawing the diagram in Figure 3 , where they presented the results of the factorial analysis performed and the influence of the main factors on the evolution of the average indicator of SGR. We compared the SGR indicator with the sales growth rate $(\mathrm{g})$ to evaluate the utilization of the growth potential of the industrial enterprises, Figure 4. Due to the comparison, we established that most enterprises have a higher sales growth rate than SGR, which demonstrates the maximum use of the internal growth potential.

Figure 4. Evolution of the average values of the SGR and $g$ indicators in the domestic industrial enterprises for the years 2013-2017

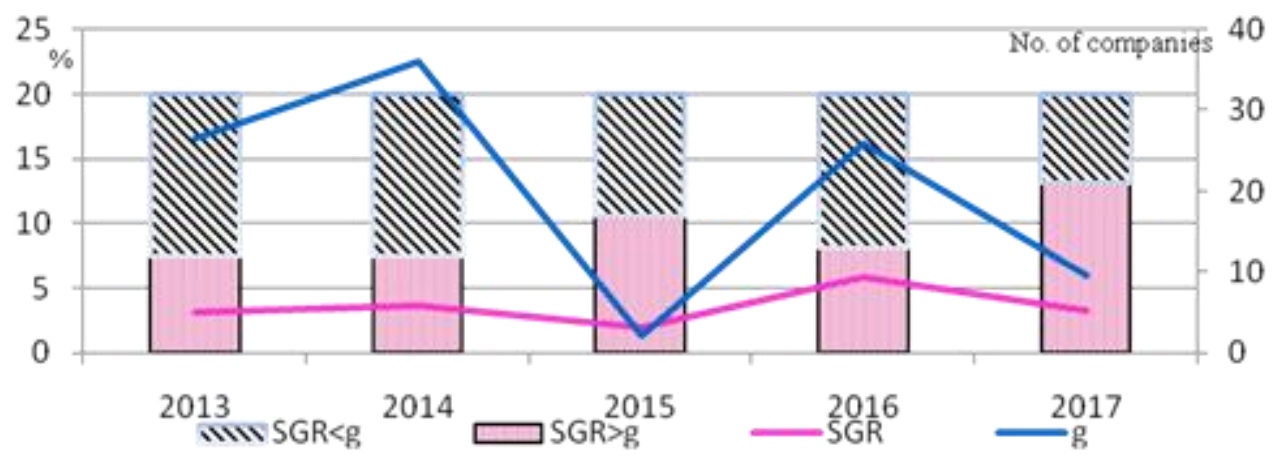

Source: Authors' representation based on the results of his estimations

Analysing the correlation between SGR and g for the years 2013-2017 on industrial enterprises, we established the following:

- in 2015 and 2017, we found SGR> g inequality for most enterprises, respectively, we can say that, during these years, the enterprises reached lower sales vis-à-vis the internal growth reserves of the enterprise;

- $\quad$ in 2013, 2014, and 2016 we found SGR <g inequality for most of the enterprises, respectively, we can say that, during these years, the enterprises achieved higher sales vis-à-vis the internal growth reserves of the enterprise.

Based on the graphical analysis of the evolution of SGR and g, we can say that the domestic industrial enterprises achieve a higher sales growth than the domestic growth possibilities, which is achieved either by finding internal growth reserves in addition to the existing ones or by using sources of external financing.

Thus, for the financial positioning of the domestic enterprises based on the SGM, the authors elaborate the matrix "SGR - g" presented in Figure 5, the use of 
which will allow a complex evaluation of the situation and the elaboration of strategic decisions aimed at the financial resilience of the enterprise.

By analysing the evolution of the positioning of domestic enterprises within the "SGR-g" matrix, we find that the financial situation of enterprises is worsening, namely: in 2013, most industrial enterprises registered an intensive growth but were faced with the problem of the deficit of resources and in 2017, most enterprises registered a slow growth or even a decline in activity due to a surplus of resources.

\section{Figure 5. The financial positioning matrix "SGR - g" of the domestic industrial enterprises}

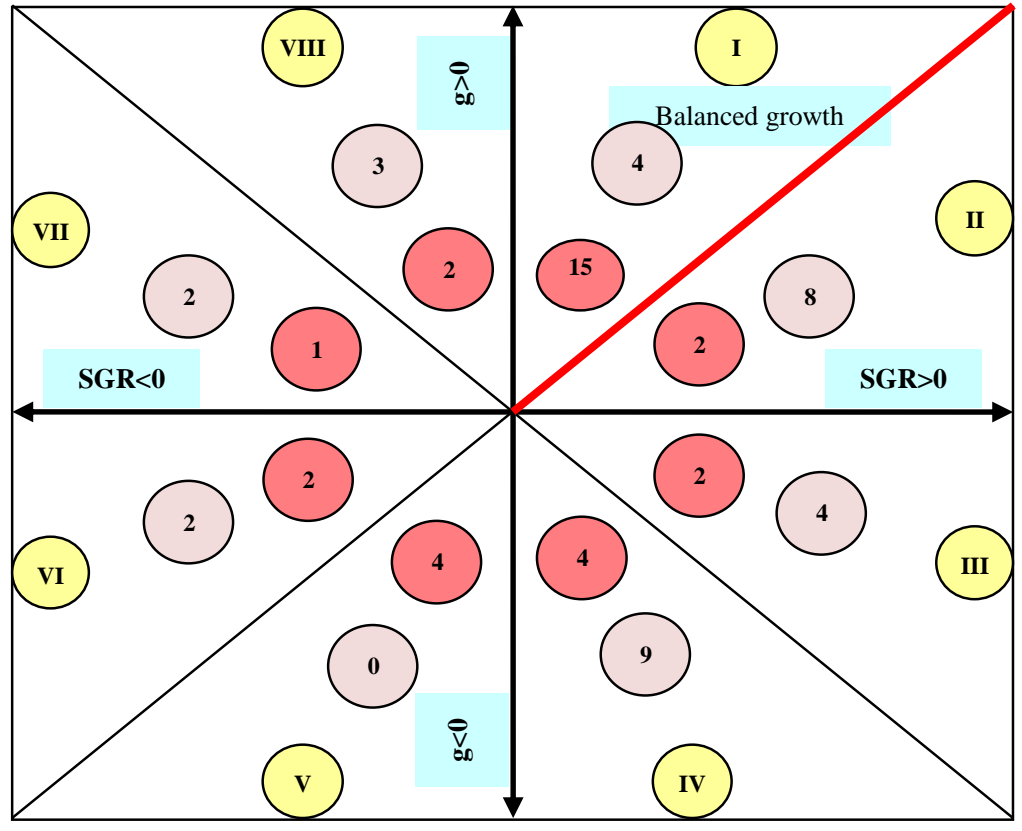

Sector no. 1 - Intensive growth / resource deficit

Sector no. 2 - Slow growth / surplus of resources

Sector no. 3 - Incipient decline / surplus of resources

Sector no. 4 - Progressive decline / surplus of resources

Sector no. 5 - Progressive decline / critical resource deficit

Sector no. 6 - Incipient decline / critical resource deficit

Sector no. 7 - Slow growth / critical resource deficit

Sector no. 8 - Intensive growth / critical resource deficit

Source: Authors' representation based on his estimates

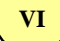

Sector number

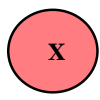

Year 2013, x enterprises

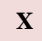

Year 2017, x enterprises 


\subsection{Results of applying the strategic management model of the enterprise value}

After an analysis of the results of the PRO indicator estimates for the domestic industrial enterprises for the years 2012-2017, we will classify the analyzed enterprises according to the results recorded for the PRO indicator in the following table.

Table 3. Generalized evaluation of the results of the determination of the PRO indicator in the domestic industrial enterprises for the years 2012-2017

\begin{tabular}{llrrrrrr}
\hline No. & \multicolumn{1}{c}{ The evaluation result } & $\mathbf{2 0 1 2}$ & $\mathbf{2 0 1 3}$ & $\mathbf{2 0 1 4}$ & $\mathbf{2 0 1 5}$ & $\mathbf{2 0 1 6}$ & $\mathbf{2 0 1 7}$ \\
\hline 1. & Positive result by enterprises, units & 12 & 11 & 13 & 10 & 8 & 10 \\
\hline 2. & Negative result by enterprises, units & 20 & 21 & 19 & 22 & 24 & 22 \\
\hline 3. & $\begin{array}{l}\text { Average value of the positive result, } \\
\text { thousands euro }\end{array}$ & 290,1 & 362,9 & 529,3 & 909,1 & 1789,9 & 1836,9 \\
\hline 4. & $\begin{array}{l}\text { Average value of the negative result, } \\
\text { thousands euro }\end{array}$ & $-535,2$ & $-507,5$ & $-438,2$ & $-676,4$ & $-559,4$ & $-654,9$ \\
\hline 5. & General average, thousands euro & $-225,8$ & $-208,3$ & $-45,2$ & $-180,9$ & 27,9 & 123,8 \\
\hline 6. & Profitability of invested capital, \% & 11.57 & 11.25 & 12.53 & 14.11 & 17.69 & 15.46 \\
\hline 7. & WACC, \% & 15.34 & 14.82 & 13.39 & 16.95 & 17.37 & 13.99 \\
\hline
\end{tabular}

Source: Authors' calculations based on the financial reports of industrial enterprises

The overall average value of PRO during the analyzed period has evolved positively, from recording a negative result in 2012 of $-225,8$ thousand euro to reaching a positive result in 2017 , i.e. of 123.8 thousand euro. But this increase was not caused by the increase in the number of enterprises with a positive result of the PRO indicator but by the improvement of the results of the enterprises with a positive result of the PRO indicator.

The negative result shows us that most of the domestic industrial enterprises do not cover their expenses with all the capital involved in the activity of the enterprise for the operating profit of the enterprise. Therefore, the share capital of the enterprise is not remunerated to the minimum necessary and there is a risk that the share capital would migrate to other branches where it has higher profitability.

For a relevant analysis of the indicator of the operational residual profit at the domestic industrial enterprises, we will resort to a graphical illustration, shown in Figure 6.

Based on the graphical analysis of the results of the indicators in Figure 6, the main cause of the registration of a negative PRO in the domestic enterprises is highlighted, that is, the inferiority of the return on capital invested indicator compared to the WACC.

Following the factorial analysis of PRO, the authors state that, in order to increase the value of the analyzed enterprises, it is necessary to solve the problem of establishing the optimal structure of the company's capital. 
Figure 6. Analysis of the PRO indicator for the period 2012-2017 in correlation with the profitability of the invested capital and WACC

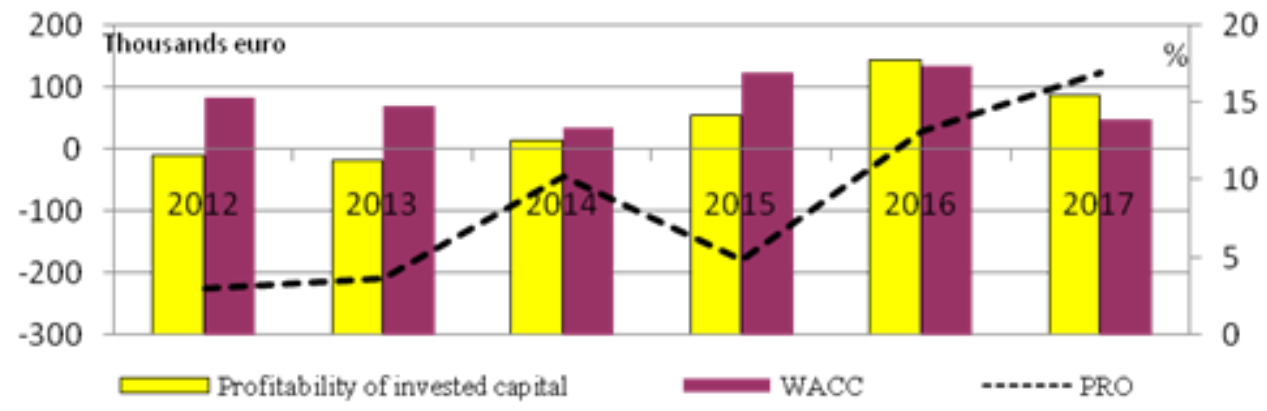

Source: Authors' representation based on the financial reports of the enterprises

The evaluation of the results of the estimation of the PRN indicator on the domestic industrial enterprises is summarized in the following table:

Table 4. Generalized evaluation of the results of the PRN indicator determination in the domestic industrial enterprises for the years 2012-2017

\begin{tabular}{clrrrrrr}
\hline No. & \multicolumn{1}{c}{ The evaluation result } & $\mathbf{2 0 1 2}$ & $\mathbf{2 0 1 3}$ & $\mathbf{2 0 1 4}$ & $\mathbf{2 0 1 5}$ & $\mathbf{2 0 1 6}$ & $\mathbf{2 0 1 7}$ \\
\hline 1. & Positive result by enterprises, units & 1 & 2 & 2 & 2 & 1 & 2 \\
\hline 2. & Negative result by enterprises, units & 31 & 30 & 30 & 30 & 31 & 30 \\
\hline 3. & $\begin{array}{l}\text { Average value of the positive result, } \\
\text { thousands euro }\end{array}$ & 424,7 & 137,3 & 191,9 & 126,7 & 660,5 & 982,6 \\
\hline 4. & $\begin{array}{l}\text { Average value of the negative result, } \\
\text { thousands euro }\end{array}$ & $-794,8$ & $-886,2$ & $-781,2$ & -1068 & $-928,9$ & $-783,1$ \\
\hline 5. & General average, thousands euro & $-756,6$ & $-822,2$ & $-720,4$ & $-993,3$ & $-879,2$ & $-672,7$ \\
\hline
\end{tabular}

Source: Authors' calculations based on the financial reports of industrial enterprises

In the period analyzed during the years 2012-2017, we find that the number of enterprises with a positive result is constant and falls within the range of 1-2 enterprises, respectively, and that the number of enterprises with a negative result is constant within the range of 30-31 enterprises.

The negative result shows us that most domestic industrial enterprises generate a return on equity lower than the cost of equity, respectively, the authors believe that joint-stock enterprises should have strategies to increase the return on capital involved in the activity of the enterprise or adopt policies to optimize this capital. 


\subsection{Results of applying the econometric model for estimating enterprise resilience}

In the estimation of the bifactorial model based on the financial data of the enterprises in the sample selected for the period 2012-2017, with the support of the Eviews 8.0 program, the author obtained the following regression equations:

$$
\operatorname{Cap}_{i}=-23854,33+0,5125 \times C P_{i 0}^{V B}+0,2603 \times \frac{P R N_{i}}{0,15},
$$

After testing the estimated model, the coefficient of determination of $\mathrm{R}^{2}$ demonstrated a high value $\mathbf{- 0 . 8 9 6 6}$, which certifies that in $89 \%$ of cases there is a link between the market value of the researched companies' shares and the financial indicators estimated in the model.

The results of the control are set out in Table 5. They unequivocally show that the nullity assumptions must be rejected, and therefore the estimated quantities of the regression coefficients are true.

Table 5. Results of verification of bifactorial model hypothesis (CCP=15\%)

\begin{tabular}{lcc}
\hline \multicolumn{1}{c}{ Indicator name } & \multicolumn{2}{c}{ Coefficients of regression } \\
\cline { 2 - 3 } & $b_{1}$ & $b_{2}$ \\
\hline Standard error & 0.4576 & 0.0646 \\
\hline t-statistic & 9.8908 & 0.6385 \\
\hline t-critic (signification level 5\%) & 2.05 & 2.05 \\
\hline Conclusion on the nullity hypothesis after test results t & Is rejected & Is rejected \\
\hline The confidence interval (signification level 5\%) & \multicolumn{2}{c}{113.9376} \\
\hline F- statistic & \multicolumn{2}{c}{3.34} \\
\hline F- critic (signification level 5\%) & \multicolumn{2}{c}{ Is rejected } \\
\hline Conclusion on the nullity hypothesis after test results F & \multicolumn{2}{c}{} \\
\hline
\end{tabular}

Source: Authors' representation with the E-views program

From the results presented above, we conclude that the coefficients $b_{1}$ and $b_{2}$ are significant, therefore, the balance sheet value of equity and discounted residual profits have an impact on the market value of the company.

The results examined above refer to the case when the capital expenditure rate is set at $15 \%$. Related to this is the question: does the size of the required return on equity have an essential impact on the results of the analysis?

The results of the statistical analysis performed for different rates of return required are summarized in the following Table 6. 
Table 6. Results of bifactorial model analysis at different rates of the required return on equity

\begin{tabular}{|c|c|c|c|c|c|}
\hline \multirow[t]{2}{*}{ Indicators } & \multicolumn{5}{|c|}{$\begin{array}{l}\text { Alternative rates of return on equity required } \\
\qquad(\mathbf{C C P})\end{array}$} \\
\hline & 5 & 10 & 15 & 20 & 25 \\
\hline \multicolumn{6}{|c|}{$\begin{array}{l}\begin{array}{l}\text { Coefficients of } \\
\text { equation }\end{array}\end{array}$} \\
\hline Coefficient a & 0.5125 & 0.5125 & 0.5125 & 0.5125 & 0.5125 \\
\hline Coefficient b1 & 0.0868 & 0.1736 & 0.2603 & 0.3471 & 0.4339 \\
\hline \multicolumn{6}{|l|}{ Coefficient b2 } \\
\hline \multicolumn{6}{|l|}{ Coefficient of determination } \\
\hline $\mathrm{R}^{2}$ & 0.8966 & 0.8966 & 0.8966 & 0.8966 & 0.8966 \\
\hline $\mathrm{R}^{2}$ adjusted coefficient & 0.8806 & 0.8806 & 0.8806 & 0.8806 & 0.8806 \\
\hline \multicolumn{6}{|l|}{ Standard errors } \\
\hline$b_{1}$ coefficient & 0.0516 & 0.0516 & 0.0516 & 0.0516 & 0.0516 \\
\hline $\mathrm{b}_{2}$ coefficient & 0.0270 & 0.5407 & 0.0811 & 0.1081 & 0.1352 \\
\hline \multicolumn{6}{|l|}{ Test t (signification level 5\%) } \\
\hline t-critic & 2.14 & 2.14 & 2.14 & 2.14 & 2.14 \\
\hline t-statistic $\left(b_{1}\right)$ & 9.9349 & 9.9349 & 9.9349 & 9.9349 & 9.9349 \\
\hline $\mathrm{t}$-statistic $\left(\mathrm{b}_{2}\right)$ & 3.2099 & 3.2099 & 3.2099 & 3.2099 & 3.2099 \\
\hline \multicolumn{6}{|l|}{ Trusted intervals } \\
\hline \multicolumn{6}{|l|}{$b_{1}$ coefficient } \\
\hline the lower limit & 0.4021 & 0.4021 & 0.4021 & 0.4021 & 0.4021 \\
\hline top limit & 0.6229 & 0.6229 & 0.6229 & 0.6229 & 0.6229 \\
\hline \multicolumn{6}{|l|}{$b_{2}$ coefficient } \\
\hline the lower limit & 0.0290 & -0.9835 & 0.0867 & 0.1158 & 0.1446 \\
\hline top limit & 0.1446 & 1.3307 & 0.4339 & 0.5784 & 0.7232 \\
\hline \multicolumn{6}{|l|}{ Test F (signification level 5\%) } \\
\hline F-critic & 3.34 & 3.34 & 3.34 & 3.34 & 3.34 \\
\hline F-statistic & 56.34 & 56.34 & 56.34 & 56.34 & 56.34 \\
\hline
\end{tabular}

Source: Authors' representation with the E-views program

The results presented in Table 6 allow us to make the following general conclusion: the size of the required return is not a relevant indicator, which allows us to judge the link between market capitalization and accounting indicators of the equity value and the net residual profit. The first conclusion reached is based on the fact that when changing the equity expenditure rate:

- the free variable remains unchanged (-23854.3);

- the quantities of the coefficient $b_{1}$ remain unchanged when the CCP changes and the size of the coefficient $b_{2}$ decreases with the reduction of the equity expenditure rate but, at the same time, the coefficients for determining the regression equation remain constant $\left(R^{2}=0.8966, R^{2}\right.$ adjusted $\left.=0.8806\right)$; 
- the conclusions after the results of the t- and F- tests are unambiguous and determine the confidence in the regression coefficients.

- The estimated regression coefficients can be interpreted as follows:

- first of all, because $b_{1}=0.5125$, we conclude that each additional euro of the balance sheet value of the equity increases the capitalization of the enterprise by 0.51 euro;

- secondly, based on the coefficient $b_{2}=0.2603$ and the capital expenditure rate accepted in this research CCP $=15 \%$, we conclude that each additional euro of the residual profit increases market capitalization of the enterprise by 0.74 euro $(0.2603 / 0.15=1.735)$. In the case of the significance of the coefficient $b_{2}$, we consider the opposite statement to be true: each euro of the residual losses determines the reduction of the capitalization within the given size limits. We mention that, in the analyzed period, most of the industrial enterprises registered a negative residual profit.

Analysing the results of the estimated econometric model, we note the existence of a positive influence of the balance sheet value of equity and net residual profit on the value of the enterprise. Moreover, we establish that the balance sheet value of equity has a greater impact on the market capitalization of domestic industrial enterprises than the net residual profit. In the author's opinion, this fact explains the existence of the negative market premium for enterprises listed on MSE on the Moldovan market. In this context, we consider it important to note that the increase in the residual profit indicator leads to a sustainable increase in the efficiency of the core business. We mention that this result can be achieved by using the developed management models without attracting additional capital resources.

\section{Conclusions}

Based on the analysis of the evolution of SGR and g, we conclude that industrial enterprises in the Republic of Moldova achieve a higher sales growth than domestic growth opportunities, which is carried out either by finding internal growth reserves in addition to the existing ones or by using sources of external financing.

Analysing the evolution of the positioning of domestic enterprises within the "SGR-g" matrix, we find that the financial situation of enterprises is worsening, namely: in 2013, most industrial enterprises registered an intensive growth but faced the problem of resource deficit and, in 2017, most companies experienced slow growth or even decline in activity due to a surplus of resources. This is an early signal of a worsening of the financial situation of companies and a potential crisis situation, which requires the activation of the mechanism of financial resilience of companies.

The general average value of PRO during the analyzed period evolved positively, from the registration of a negative result in 2012 of -225.8 thousand euro to the achievement of a positive result in 2017 of 123.8 thousand euro. However, this was not caused by the increase in the number of enterprises with a positive result of 
the PRO indicator but by the improvement of the results of enterprises with a positive result of the PRO indicator.

The negative result recorded tells us about the fact that most domestic industrial enterprises do not cover their expenses with the entire capital involved in the activity of the enterprise from the account of the operational profit of the enterprise. Respectively, the capital of the company's shareholders is not remunerated to the minimum necessary and there is a risk that the share capital will migrate to other branches where it will register higher profitability. The main cause of the negative PRO registration in the domestic enterprises is the inferiority of the indicator of the return on invested capital compared to WACC.

Following the factorial analysis of PRO, the authors state that, in order to increase the value of the analyzed enterprises, it is necessary to solve the problem of establishing the optimal structure of the company's capital. During the analyzed period, 2012-2017, we find that the number of enterprises with positive PRN is constant and falls in the range of 1-2 enterprises, respectively, the number of enterprises with a negative result is constant in the range of 30-31 enterprises.

The negative result shows us that most domestic industrial enterprises generate a return on equity lower than the cost of equity, respectively, we conclude that another objective of financial resilience is to develop strategies to increase the return on capital involved in the activity of the company or to adopt policies of optimization of this capital.

The econometric model shows the existence of a positive influence of the balance sheet value of equity and the net residual profit on the value of the enterprise. We can say that financial resilience, based on the value of the enterprise, established according to the market capitalization can be achieved based on the balance sheet value of equity and residual profit. Thus, based on the research results, we conclude that each additional euro of the balance sheet value of equity increases the capitalization of the enterprise by 0.51 euro and each additional euro of residual profit increases the market capitalization of the enterprise by 0.74 euro. We mention that the results obtained in the enterprises of the Republic of Moldova are close to the results obtained by Bukhvalov and Volkov (2005) on the Russian market and Ashbaugh and Olsson (2002) and Couteau et al. (2001) on other markets.

\section{References}

Aghimien, D., Oke, A. and Aigbavboa, C. (2018), Barriers to the adoption of value management in developing countries, Engineering, Construction and Architectural Management, 25(7), pp. 818-834. https://doi.org/10.1108/ECAM-04-2017-0070

Angulo, A., Mur, J. and Trívez, F. (2018), Measuring resilience to economic shocks: An application to Spain, The Annals of Regional Science, 60(2), pp. 349-373. https://doi.org/10.1007/s00168-017-0815-8 
Ansoff, I. (2009), Strategicheskiy menedzhment. Klassicheskoye izdaniye, Saint Petersburg: Piter.

Ashbaugh, H. and Olsson, P. (2002), An Exploratory Study of the Valuation Properties of Cross-Listed Firms IAS and U.S. GAAP Earnings and Book Values, The Accounting Review, (77)1, pp. 107-126. https://doi.org/10.2308/accr.2002.77.1.107

Ayvazyan, Z. and Kirichenko, V. (1999), Antikrizisnoye upravleniye: prinyatiye resheniy na krayu propasti, Problemy teorii i praktiki upravleniya, 4, pp. 2-8.

Bodie, Z. and Merton, R. (2004), Finance, Cambridge: Pearson Education.

Brealey, R., Mayers, S. and Allen, F. (2020), Principles of Corporate Finance, New York: McGraw-Hill Education.

Bukhvalov, A. and Volkov, D. (2005), Issledovaniye zavisimosti mezhdu pokazatelyami fundamentalinoy tsennosti i rynochnoy kapitalizatsiyey rossiyskikh kompaniy, Saint Petersburg University Bulletin, 8(1), pp. 26-43.

Chernozub, O. (2010), Jizni posle krizisa: stoimostnoy podkhod $k$ upravleniyu chastnoy kompaniyey, Moskow: Alipina Pablisher.

Copeland, T., Koller, T. and Murrin, J. (2000), Valuation: measuring and managing the value of companies, New York: John Wiley \& Sons.

Courteau, L., Kao, J. and Richardson, G. (2001), Equity Valuation Employing the Ideal Versus Ad HocTerminal Value Expressions, Contemporary Accounting Research, 18(4), pp. 625-661. https://doi.org/10.1506/77TK-1N3Q-82QU-UATR

Damodaran, A. (2012), Investment valuation: tools and techniques for determining the value of any asset, Hoboken, New Jersey: John Wiley \& Sons.

Evans, F. and Bishop, D. (2001), Valuation for M\&A: Building Value in Private Companies, New York: John Wiley and Sons.

Fingleton, B., Garretsen, H. and Martin, R. (2012), Recessionary shocks and regional employment: Evidence on the resilience of UK Regions, Journal of Regional Science, 52(1), pp. 109-133. https://doi.org/10.1111/j.1467-9787.2011.00755.x

Ioniță, I. (2007), Evaluarea sistemelor tehnico-economice, București: Editura Economică

Ivashkovskaya, I., Konstantinov, G. and Filonovich, S. (2004), Stanovleniye korporatsii v kontekste zhiznennogo tsikla organizatsii, Rossiyskiy zhurnal menedzhmenta, 2(4), pp. 19-34.

Ivashkovskaya, I. (2021), Modelirovaniye stoimosti kompanii. Strategicheskaya otvetstvennosti soveta direktorov, Moskow: Infra-M.

Jensen, M. (2001), Value Maximization, Stakeholder Theory, and the Corporate Objective Function, Journal of Applied Corporate Finance, 14(3), pp. 8-21. https://doi.org/10.1111/j.1745-6622.2001.tb00434.x

Gordon, M.J. and Shapiro,E. (1956): Capital Equipment Analysis: The Required Rate of Profit, Management Science, 3, pp. 102-110. 
Kim, S., Lee, Y. and Nguyen, V. (2016), Barriers to applying value management in the Vietnamese construction industry, Journal of Construction in Developing Countries, 21(2), pp. 55-80. https://dx.doi.org/10.21315/jcdc2016.21.2.4

Korotkov, E. (2012), Antikrizisnoye upravleniye, Moscow: INFRA-M.

Martin, R. (2012), Regional economic resilience, hysteresis, and recessionary shocks, Journal of Economic Geography, 12(1), pp. 1-32. https://doi.org/10.1093/jeg/lbr019

Martin, R. and Sunley, P. (2015), On the notion of regional economic resilience: Conceptualization and explanation, Journal of Economic Geography, 15(1), pp. 1-42. https://doi.org/10.1093/jeg/lbu015

Modigliani, F. and Miller, M. (1958), The cost of Capital, Corporation Finance, and the Theory of Investment, American Economic Review, 48(3), pp. 261-297.

Patel, P., Guedes, J., Pagano, M. and Olson, G. (2020), Industry profitability matters: The value of sustainable growth rate and distance from bankruptcy as enablers of venture survival, Journal of Business Research, 114, pp. 80-92. https://doi.org/10.1016/j.jbusres.2020.04.004

Penman, S. and Sougiannis, T. (1998), Comparison of Dividend, Cash Flow, and Earnings Approach-es to Equity Valuation, Contemporary Accounting Research, 15(3), pp. 343-383. https://doi.org/10.1111/j.1911-3846.1998.tb00564.X

Penman, S. and Yehuda, N. (2009), The pricing of earnings and cash flows and an affirmation of accrual accounting, Review of Accounting Studies, 14(4), pp. 453-479. https://doi.org/10.1007/s11142-009-9109-4

Porter, M. (2008), On Competition, Boston: Harvard Business School.

Reilly, R. and Schweihs, R. (2014), Guide to Intangible Asset Valuation, New York: American Institute of Certified Public Accountants.

Rose, A. (2007), Economic resilience to natural and man-made disasters: multidisciplinary origins and contextual dimensions, Environmental Hazards, 7(4), pp. 383-398.

Rose, A. and Liao, S. (2005), Modeling regional economic resilience to disasters: a computable general equilibrium analysis of water service disruptions, Journal of Regional Science, 45(1), pp. 75-112. https://doi.org/10.1111/j.00224146.2005.00365.x

Rutgayzer, V. (2014), Otsenka stoimosti biznesa, Moscow: Maroseyka.

Tsvetkov, V. (2012), Tsikly i krizisy: teoretiko-metodologicheskiy aspekt, Moskva-SanktPeterburg: Nestor-Istoriya.

Volkov, A., Žickiene, A., Morkunas, M., Baležent, T., Ribašauskiene, E. and Streimikiene, D. (2021), Multi-Criteria Approach for Assessing the Economic Resilience of Agriculture: The Case of Lithuania, Sustainability, 13(2370), pp. 1-16. https://doi.org/10.3390/su13042370

Walsh, C. (1996), The key management ratios, London: Pitman Publishing.

Wolman, H., Wial, H., Clair, T. and Hill, E. (2017), Coping with Adversity: Regional Economic Development and Public Policy, Ithaca, NY: Cornell University Press. 